\title{
Between Traditional Christian Theology and Moral Parables of African Popular Films: Communicating Gospel Values Contextually
}

\author{
Innocent Ebere Uwah \\ *http://dx.doi.org// 0.43 |4/ujah.v17i3.7
}

\section{Abstract}

The assumption that films are works of arts that basically create illusion of realities can sometimes be misleading. Like every other communication tool in human history, they do not only interrogate the society but also chart its course as moral compasses' leading to self reflection and conscience formation. Thus, they are at times theological communications salvaging the dark themes of human existence with integrating symbols and dramatic parables imbued with didactic narratives that challenge the epistemic ambivalences of traditional theologies. In this chapter that explores the interface between filmic parables and traditional Christian theology, the thrust is to showcase how African cinematic representations resonate with audiences contextually in a fusion of communion and communication that questions the critical faith statements and dogmatic doctrines of theological taxonomies in the presence of people's everyday hardships. Thus by textualising key scenes in films like Cry Freedom (1987), Act of Faith (2008) and Onyebuchim (2010) this paper reviews the challenges of pastoral and theological communications in Africa and beyond; while calling for revolutionalised demonstration of the 'search for values' around cultural meanings.

Key Words: Christian theology, Moral parables, Popular films, Communications and Context. 


\section{Introduction}

The abstract nature of classical Christian theologies grounded in rigorous apologetics can sometimes be problematic in pastoral evangelisation. Especially when high sounding words and themes far removed from people's everydayness are used, the issue of communicating Christ to effect positive change, healing or consolation can be practically challenging. In such a framework, the dogmatic nature of Christian doctrines can only be construed as protecting the 'status quo' under shadow of mysteries and faith related imaginations. Theology in this sense is usually described as "faith seeking understanding - fides quaerens intellectum" where the proclivity to explain preternatural realities with epistemic terms becomes deeply utopian. But considering Jesus' use of parables contextually to evangelise the people of his time in comparison to such classical Christian theological exegesis commands a paradigm shift that practically encourages reviewing contexts and language of communication in evangelisation. This is called 'contextual theology' which refers to the "process of making Gospel symbols of pardon, service and compassion part of the way people see the world [which] is true evangelisation" (Calvin, 1989: 30).

Films as aspects of cultural industries apply this kind of theological services in most representations by making use of symbols, codes and languages that are radically twisted to give pleasure while communicating messages of values contextually. Dialectically they create meanings that resonate with the ordinariness of people's everyday life's circumstances. Malone describes this as when "cinema renders stories (words about deeds) into images, revealing human strengths and weaknesses, probing the mysteries of life and death" (2005: 7). 
Films explore the ontological paradoxes that characterise the dynamics of human existence. Like communication theology that considers the science of God from the context of contemporary cultures (Plude, 20II: 9) they are public communications that are produced and consumed on the basis of people's resonance with their themes. Thus, in this way, they help humankind to search for values or affirm what Malone calls "the dramatising of values, of parable-telling on screen" (2005: 14). In this chapter that explores the interface between filmic parables and traditional Christian theology, the thrust is to demonstrate how African cinematic representations are able to resonate with audiences contextually in a fusion of communion and communication by responding to people's everyday needs with some integrating symbols. This is done by analysing a chosen filmography of African cinema to butress the notion of pastoral communication in context: a situation where people's faithvalues are shared and deeper questions of life's paradoxes are resolved. But just before delving into the rigours of doing this, suffice to first of all explicate the working concepts of this paper.

\section{Theology and its Ramifications}

The concept of classical theology emerged historically after the thirteenth century to refer to speculations about God (Fiorenza, 1991: 6). It is the discipline under which all discourses about the existence and knowledge of God are carried out. Thus, rooted in metaphysical argumentations, it comes under various sub-categories like Christology, Ecclesiology, Dogmatic theology, etc generally framed around the notion of God's salvific encounters with human beings and their concommittant response to his loving invitation. ${ }^{2}$ Scholars like Makumba (2006) identifies two kinds of approach to Traditional Christian theology exemplified in the 
writings of both St. Thomas Aquinas and St. Augustine of Hippo. Particularly in Thomistic theology he observes the presence of some elements of rational and revealed theologies of the Catholic Church which he assents as follows:

rational theology is where by unaided reason, one could attain theological truths about God's existence, his attributes and the immortality of the soul. Revealed theology has to do with certain truths that are beyond the scope of unassisted human reason and must be disclosed through revelation. These are truths like the Trinity, Incarnation, supernatural grace and human supernatural destiny (2006: 16).

All of these and more present a general clue to the methodology and science of theology in academic theological institutions which apart from their abstract rigours to arrive at the knowledge of God leave much to be desired in terms of answering to contextual and experiential human problems. Especially in pastoral contexts of rural villages where oral tradition is still the order of the day, it is hard to conceive how abstract theological truths could practically respond to people's inner longings for healing and aspirations.

Discovering the inadequacy of the classroom methodology of classical Christian theology in answering contextual problems, the Catholic Church responded with the call for "inculturation theology", having in mind to create model environments for responding to issues of concerns in cultural communities. Onwubiko defines inculturation as "a new vision of an old problem in the Church or a new approach to a solution of an old problem, or still a new interpretation of an old solution of the Church and culture encounter. It came 
into use after the Second Vatican Council ...intimately concerned with the dialogue between Christianity and culture through the Church" (1992: I). This dialogue, the Pontifical Council for Culture in the Catholic Church considers as extremely important when dealing with people in their everyday contexts especially in the area of evangelisation. Thus, speaking on this, the Council observes that "culture is so natural to man that human nature can only be revealed through culture. In a pastoral approach to culture, what is at stake is for human beings to be restored in fullness to having been created "in the image and likeness of God." (Gen I: 26)" (1999: 8). Thus, the call for inculturation is not only pastoral but also salvific more so, because every human being is a product of a culture and ought appropiately to be approached with the intention of realising salvation within such contexts. In the words of Bisong, "inculturation is an essential aspect of the need to apply the gospel as liberative in all aspects of the social and historical contexts of the believer." (2000: 88).

Liberation in the context of inculturation theology is bringing life to people's cultural circumstances in order to make them experience the love of Christ and be able to model their life after his own example. It is practicalising contextual theology and pastoral communication with the view of bringing about rejuvenation of the spirit and renewal of the mind of individuals. Ofoegbu calls this "Christonization" whereby Christians are practically crystalized into becoming Christ-like and seeing with the eyes of Christ in their cultures (1998: 80) while White discusses it as "inculturated incarnation" when he states that "the incarnation is a continuing, ongoing process of evangelising cultures and evangelising through culture and history. Christianity exists as a series of great 
religio-cultural revitalisations that generate new forms of community...." (1998: 17).

Drawing from Jesus' own method of doing contextual theology therefore, the argument of this chapter correlates with the view that "although [academic] information may be necessary at some stage, the first step is to reach out to discouraged and demoralised people in compassion to reveal the love of God to them" (Calvin, 1989: 18). This is what Nolan identifies by calling for an urgent return to the pastoral model of Jesus who rather than approach issues with high sounding theological vocabularies in his time used meaningful metaphors to address people's conditions as human beings. This, he did by using subversive stories, parables and transformational relationships to create contexts of faithsharing encounters with his audiences. On this note he remarks that "the starting point of Jesus' spirituality ... included the awareness that God... loves and forgives all men, women and children unconditionally." (2006: 109).

Most films dramatise this kind of revealed theologies that border on people's existential conditions as a method of evangelisation in their storylines. Thus, the use of metaphors and existential paradoxes of life couched as screen parables is where pastoral communication is labelled 'contextual theology' in praxis which this paper aims at dovetailing by triangulating between classical Christian theology and the contextual moral parables of African cinematic representations. But again with the usual method of underscoring the working notion of some key terms applicable to this work, it would still be appropiate to answer the question: what is "parable?" 


\section{Parable in Bible and Film: A Case of Intersecting Connection}

It is arguable to say that every movie construction is a narrative that thrives on contextual challenges and resolutions. This is because in order to engage audience's pleasure, they are skillfully twisted with coded symbols to provide "a type of vicarious satisfaction that is central to the aesthetic experience ...[which] depends on an awareness of the conventions that the artist is following or breaking" (Messaris, 1994: 29). Among the conventions that filmmakers adopt in their career therefore is the interrogation of people's everyday life settings by means of the metaphors they use and the parables they create to explore them. Thus, parables are veritable tools in the hand of movie makers to communicate messages of value in such a way that following the suspense imbued in them new knowledge is acquired by audiences.

Biblically "a parable is...a simple picture, event or relationship taken from daily life with an arresting feature by which the listener is challenged to enter into an active search for discovering deeper spiritual meaning in the simpler realities described." (Leske, 1998: 1253). In this sense, parables are constructed storylines that necessarily bring up moral and personal questions in the search for values. They may not only contradict social structures but raise awareness to actual realities which otherwise could not have been expected to happen. In this context Leske believes that "a listener ... [or a viewer] is not expected to be a passive recipient of [a] teaching [or a (re)presentation] but has the task of investigating its meaning on various levels, finding a new relevance or application amid the changing facets of human life." (1998: 1296). This typically is the impression got from the parables of Jesus in the bible where the metaphors used 
to engage audiences' attention are constructed to communicate faith-related messages contextually. Nolan interprets the story of the good Samaritan for instance to denote this communicative value of parables in a challenging situation, thus:

the story of the Samaritan who helps a robbed and injured Jew, while a Jewish priest and Levite walk by on the other side (Lk 10: 30 -37) subverts all the myths about Jews and Samaritans .... Jesus is saying to his fellow Jews not only that they should include the hated Samaritans in their love of neighbour but also that they might even learn something from a Samaritan about loving one's neighbour (2006: $82-83)$.

Thus, like the teaching of Jesus, movie parables are morally didactic in nature and not necessarily shrouded in high sounding dogmatic vocabularies and themes. They 'theologize' in the sense of what White describes as "the process of discerning the presence and action of God, inviting us to work with the transcendent in the construction of God's kingdom." (2003: 20). In the reading of some Nigerian popular films, some viewers in a focus group interview help to underscore the communicative nature of movie parables that does not only portray the action of God in human everydayness but also radically dramatises the paradoxes of social structures and ideological binary oppositions. Thus, when asked if they had ever recommended movies to other people because of their teaching values to contextual issues, some of the focus-group interviewees ${ }^{3}$ responded as follows: 
Viewer I: I once recommended a movie to my friend and until date I call it my best. It is entitled World Apart by Kenneth Okonkwo popularly known as Andy. It is about a wealthy young man desiring to marry from a very poor family. Since his parents are highly influential in the society, they did not want the decision of their son to happen because they are wealthy. They felt that for a Prince to desire to marry the poor girl, a maid for that matter, is a condescension from glory to poverty because they are of two worlds apart. But the man, Kenneth Okonkwo, fought against the impression of his parents to the extent of disguising the girl with fashion and presents. During her presentation to the palace, the parents could no longer recognise that she is the maid whom they had rejected earlier because he dressed her in a wealthy fashion, sponsored her education, treated her like a princess inspite of her low background and eventually married her. I had to recommend it to a friend to follow where his love leads him. The lesson is that though they are of two (different) worlds apart due to social status, they can reconcile it with human understanding.

What one notices in the interpretation of this synopsis by this respondent is that the hegemonic display of social power structures after all is uncalled for. Here, the aristocratic family does not wish to associate with the lower class of people because they have prided themselves as superior, richer and more favoured, hence the encoders of the movie used the role of their son to problematise their status in the society while interrogating such a misjudgment of integrity on people's background. The paradox twisted into a parable here is that "treasure" sometimes is often disguised and may 
not necessarily be found in commonly expected havens. This also is corroborated in the answer given by the second respondent who discusses the significant entrepreneural progress made by a seemingly despised pauper after receiving help from an unknown "good Samaritan" that eventually made him, a "former beggar" become a successful rich ambassador of a society that originally looked down on him. Thus, he narrates:

Viewer 2: The name of the film is Biggest Boy in Town. I have a friend whose life relates to the story of the main character depicted in the film. When this 'guy' finished his primary school education, there was nobody to sponsor him further. He spent a lot of time at home in the village doing nothing. The parents had died and his uncles did not want to help him. No person actually wanted to help him from the village. But as God would have it, some day he met a man who helped him when he least expected it and trained him in business. Today, he is doing very well with the name Abu Ventures. I recommended it to my friend whose life story is identical to the depiction of the film. So with this story I can tell you that the film industry is challenging what is happening in our society.

Actions like those described in the above mentioned two movies resonate with viewers because of the application of the integrating symbols of poverty, drive for survival and uncommon help that conventionally speak to their conditions in life. In other words, the language of communication and the context of actions in the films are identifiable with their own everydayness even though in a challenging manner. It is like the parables of Jesus in the Scriptures that speak to the 
situation of his hearers in the communities of his time. Thus, even though some of the people are socially labelled sinners, lepers, prostitutes, possessed by evil spirits, poor, sick and dejected or lost, the action of Jesus to them, like those of the "helpers" in the two films mentioned above is symbolic in communicating God's love in their contexts in such a convincing way that hope is restored and life is renewed for them.

In describing the nature of this method of the application of "parables" and "transformational relationships" to people's situational contexts, Nolan describes Jesus' approach as believeably radical, thus:

while he was radically critical of his society, Jesus was never judgmental.... His attitude to the people of his time who were labelled 'sinners' was strikingly different from the attitude of other religious leaders...The lostness or brokenness of people can hardly be exaggerated. The peasants ...were caught up in a spiral of violence with ever increasing taxation and debt, less bread and no food security, more disease and mental illness. Together with the beggars, the prostitutes and the tax collectors, they were made to feel unclean, guilty, punished by God, and vulnerable to attack by evil spirits...Jesus' respect for the dignity of everyone he encountered was boundless. He treated each individual as unique and lovable - whether that person was a blind beggar, an epileptic, or a Roman Centurion (2006: 109 - I I3).

Thus, all of these in practical terms point to the kind of parables that resolve tensions which Jesus applied. They do not only challenge the "status quo" of existence but also help 
re-think the hegemonic way that present day human society views things. Hence it calls for a paradigm shift in pastoral communication efforts at building humanity into God's own community where love and justice reigns. It also advocates a kind of spirit-led relationship where peace is a heritage and everybody is considered a brother or sister in the one family of God often considered in African ontology as found "on the principles of community spirit, familyhood, teamwork, community sharing, togetherness, known in Africa as Ujamma"4 (Onwubiko, 1999: 7). By this therefore is pastoral communication meant to interrogate the model of evangelisation operative in the Church in order to harness faith as the principle of absolute dependence on God that helps humankind earn freedom and salvation through Christ who "reveals" God in life's situations which most movie representations encoded with some symbolic elements of gospel values attempt to capture as shall be seen shortly.

\section{African Popular Films and Screen Parables}

While it is common presently to attribute the word "popular" to some aspects of African media to signal dynamism, massive appeal to the public and resonance with fans, the concept originally was used in a disparaging sense to denote whatever is considered to be of low class status. Barber uses a dialogue scene in one of the Shakespearean plays entitled Henry $V$ to buttress the pejorative thrust of this word, thus:

Discuss unto me; art thou officer?

Or art thou base, common, and popular? ${ }^{5}$

By this statement and question, the word "popular" does not signify "acceptance" at all but derogatively describes what is merely "ordinary". It denotes being insignificant among other 
things which its usage in Africa Haynes remarks had some political undertone when the concept emerged for the first time in the 1980s. According to him, the term "had to struggle against leftist condemnation of "the popular" as politically useless or worse: a repository of false consciousness that prevented the masses from seeing the truth of their condition and acting to change it." (2000: 15). Thus the concept was originally considered as denoting something incredible until when it came to signify "fame" and "public interest." Barber argues that it now "has a focus for approbation and championship, to the point where anything produced by "the people" is automatically valued." (1997: 3). Thus, the word "people" here stands out as referring to the standard bearers of cultures and the determinants of what is engaging in storylines to the extent of gaining an acceptable popularity among all. Particularly in relation to Nigerian popular films, Haynes opines that "the Nigeria video films are an example of popular ...belonging to the informal sector of the economy, and as such closer to, if not direct expressions of, a popular African point of view." (2000: 29).

African cinemas, exemplified by the Nigerian video films therefore are expressions of popular viewpoints on issues concerning Africa and her neighbours, otherwise representations of Africa concerning her contextual situation in relation to others. The films do not only address realities of Africans living in the continent of Africa, but also those of Africans in the Diaspora and those of the people of the global South especially India, Philippines and Asia by extension due to some kind of commonly shared ontological aesthetics and iconography. Larkin (2007: 348) emphasizes this view by outlining how African cinematic representations "is a contingent facet of the global media" by recasting Bollywood's (Asian) influence on Hausa productions as well 
as (Western) Hollywood's influence on Southern Nigerian (Nollywood's) productions. Thus, in discussing the itineraries of Indian Cinema and African Videos as part of Global media, he argues that "the sense of similarity and difference is produced by the iconography and mode of address of the films themselves...." (2007: 344). In other words, the issue of iconography in the films refers to conventional contextual symbols and images that are applied in the construction and consumption of their dramatised messages. They break barriers and trans-nationalise the films in such a way that encoded messages are meaningful to audiences. Hence, what is said of African popular cinema can be extensively applied to the generality of a wider audience including people of the global South who hold cultural worldviews and similarities with them as necessitated by communalism which they share as a way of life.

African cinemas address human situations from the point of view of their worldviews. In the words of Barlet, the films invite audiences "to a genuine process of learning how to look" (2000: IX) at contextual issues that are both local and global such as: the emptiness of poverty, the savagery of injustice, the rhetoric of politics, the brokenness of individuals by terminal ailments, the hopelessness of spiritual aridity and the search for transcendental values. Thus, they respond to the need of their audiences whose everyday life situation and contexts they rehearse and interrogate. They particularly answer to their need for pleasurable engagement and at the same time signal ways of enhancing relieving succour for their crisis-ridden situations. This is what most African popular films do, not only for African audiences but especially for the generality of the people of the global South who share the complexities of the Third World geo-political conditions ${ }^{6}$ altogether. The films do not only communicate 
the gospel values of Christ in African situations but also dramatise an understanding of the deeper questions of people's everyday life contexts in their own way almost similar to the radical interpretation of contextual and liberation theologies ${ }^{7}$ of Latin America on people's circumstances. Again, like the gospel of Social Justice that is daily being crusaded by the Social Teachings of the Church in such documents like Rerum Novarum (I89I), Pacem in Terris (1963) Solicitudo Rei Socialis (1987) et cetera, these films continue to extend divine teachings of Jesus in practical demonstrations in order to challenge viewers to action.

Nolan is one author who underscores this kind of communication in the evangelisation method of Jesus as a contextual theologian in the following words:

observing the pain and suffering of the peasants and other people who were becoming poorer everyday and crying out for their daily bread, shocked by the hypocrisy and self-righteousness of so many religious leaders, moved by the 'lostness' and brokenness of many sincere people, Jesus seems to have decided that what the people needed was healing. (2006: 95).

Healing therefore is an act of restoration of these "broken" people from the state of sickness to health, wellbeing and fitness by one who understands their story. It is this that Jesus did for many and wished all to have in full as can be decoded from his statement, thus: "I came that they may have life and have it in abundance" (In 10: 10).

Instances abound where pain and misery buttress the culture of crisis surrounding people's everydayness in the world of today like those of the days of Jesus. They are not only 
depicted in newspaper news stories but also captured in cinematic representations. They are there in the faces of children hawking wares dangerously in-between moving vehicles because they have no one to send them to school. They are seen in the faces of beggars who kneel and stand at Cathedral gates looking for daily bread from the hands of passers-by and those of poor house maids labelled "witches" by their keepers since they have no one to speak out for them. This culture also occurs in moments of devastation when HIV patients are ridiculed ignominiously without help by their neighbours. It is the case where widows are forced to suffer heinous rituals on suspicion that they might have killed their husbands and in such situations as Nolan describes when he says:

Many people suffer from a debilitating guilt complex....there are those who hate themselves and blame themselves for whatever goes wrong in their lives. A surprising number of women blame themselves for being raped or assaulted. Children who were sexually abused often think it was their fault (2006: I38).

Biblically Job presents a typical picture of this crisis when in the darkest moment of his life he laments grievously due to his private sorrows, thus: "may the day perish when I was born...my only food is sighs and my groans pour out like water....For me, there is no calm, no peace, my torments banish rest." (Job 3: 2 -4; 24 - 26) Thus, the fact that most people are in crisis like Job was calls for the kind of Jesus' communication that could turn their situations around for the better. Whether in the purview of contextual theology or pastoral communication, the idea of constructing storylines 
with integrating symbols in films as this paper argues, is because most members of the community of God's people are looking for a kind of communication that could bring them the good news of salvation, sacred compassion and integral healing. April Springtime helps dramatise the urgency of this call by presenting her own life story as that of someone in a crisis ridden context. She goes to Church but had to leave in tears as soon as the preacher begins to give a sermon on abortion that reminds her of a wrong decision she made in the past. She uncontrollably weeps and narrates:

It happened again today ...I left the church abruptly, trying desperately to hide my tears. I suppose people wondered if I had become suddenly ill. I wasn't. I left to hide my tears, my shame, my sense of being a permanent pariah among God's people ....I have thought seriously, many times, of telling the children what we did.... I am too afraid.... My husband and $I$ are active in our church. We are well respected.... what would happen if we confessed to the church what we had done, years ago? ....Here is a task to which the church must be called.... Here is a need, a desperately urgent need the church must answer....It is the need to hold out God's love and forgiveness.... (1995: 27).

Like April Springtime, who agonises because of her wrong choice of abortion at a point in time and needs someone to help her see forgiveness and healing from the hand of God, most people are in need of a contextual spirituality that is not judgemental in approaching their crisis situations. They seek for a theology that is rooted in their cultural contexts and 
like Jesus in the bible can help them testify to goodness "go and tell ...what you hear and see: the blind recover their sight, the lame walk, the lepers are cleansed, the deaf hear, the dead are raised, and the poor have good news brought to them." (Mtt, I I: 4 -5, in Nolan, 2006: 95).

The argument here is that this is what most African popular films showcase, not necessarily from the point of view of casting characters in the context of the "super-priest role model" (Dipio, 2009: 88) where they are portrayed as reformers in the church or charismatic leaders of some exceptional qualities; but as communicators that help resolve dilemmas in people's life situations as well as in communities. This, Malone identifies as public communication that "dialogues about human dignity and can be used to strengthen the human rights that underlie it" (2005: 9) which guides the choice of some select movies for analysis herein. Suffice to say therefore that the movies are selectively chosen from Nigeria and South Africa to cover the ontological circumstances of the continent especially from the viewpoint of contextual crisis situations. Cry Freedom (1987) for instance is to be used to theorise the apartheid circumstances that characterised the frustrations of most black Africans in South Africa in the 1980s and the kind of responses they received, while Onyebuchim (2010) and Act of Faith (2008) are from the Nollywood stable belonging to the Christian and Traditional genres to underscore the issue of family crisis amidst active faith in God (Act of Faith) and that of the ugly trend of a culture-imposed crisis on helpless individuals by communities whose cultural and ideological mindset heightens the frustrations of communal existence (Onyebuchim). 


\section{Onyebuchim (2010) and the Crisis of a Cultural Caste System}

While films are works of arts, they are also social commentaries on the workings of the society and therefore act like agencies of interrogation to examine cultural rituals and beliefs. Onyebuchim for instance is a cultural text that interrogates the "osu" caste system ${ }^{8}$ in Igbo land while examining the fidelity of African indigenous Christians to both their cultural tenets and religious values. Like the Hollywood Slum dog Millionaire (2008) that betrays the unequal class system of Indian society while calling for harmonious adjustments, Onyebuchim thrives on the uncertainties of African society due to man-made frustrations under the hegemonic influence of cultural constructs. Directed by Ikechukwu Onyeka and starring artistes like Zack Orji, Patience Ozokwor, Chinwe Egwuagu and Comfort Bruno, this 122 minutes' movie dramatises the pains and sorrows of individuals branded outcasts in the lgbo society of Nigeria for no just reason whatsoever except that their ancestors must have been consecrated to the gods or village deities at sometime in history.

Particularly in the Igbo society of Nigeria, this caste system is traditionally referred to as "outcasts". Its history has not only been showcased on films but also widely discussed through other channels of communication. Onwubiko presents it as referring to a "particular group of people, who have been stigmatized from time immemorial as social outcasts to the point of dehumanization" (1993: 25). These set of people are so designated because they are said to be culturally consecrated to the deities of the land as their slaves. Thus, by becoming the slaves of the gods, they are the "untouchables" of the society who are not allowed to mingle with other free 
citizens since they are themselves unclean, ostracised and good only as sacrifices to the deities to whom they belong.

In highlighting the historical origin of the caste system, Onwubiko argues that the "osu system has its roots in the practice of human sacrifice in Igboland. The osu was a person sacrificed to a deity by a community or a group of people or a family.... Occasionally, circumstances arose in which human sacrifices were believed to restore harmony....this was seen as imperative if the deity were to continue it's believed task of protecting the community during the coming year....." (Onwubiko 1993: 25). Iheanacho on his own rationalizes on the possible reasons behind the emergence of the caste system in the first place and argues that:

The Igbo people, especially in the pre-Christian [era] practiced what could be described as a ritual and shrine-based religion. This was a type of religion that fed off continuous sacrifices and services at the shrines. It was therefore a labourintensive religion that needed constant supply of labour and man-power for its numerous rituals and services to continue to thrive.... The choices available to it from the beginning were stark. Either it created a hereditary priesthood or shrine ministers from among its own people as was the case in ancient Israel with the Levites, or it purchased its shrine workers who would see to the continuous services of the deities at their shrines. The traditional Igbo religion opted for the latter (2012: 517)

But whatever the reason for the existence of the caste system in Igboland, the film Onyebuchim is encoded to raise questions on the culture of injustice on this class of individuals by their community members, who, more or less 
are Christians called to love after the mind of Christ. Even though, an Igbo production, strategically filmed in Owerri, Imo State, popularly called the heartland of the South-Eastern part of Nigeria, in Igbo language with subtitles in English, the text speaks not only to the natives of the Igbo geopolitical enclave but also to people of similar cultures. In this way, it extends its interrogations to the cultures of most people of the global South like the Indians, the Philippines and other communalistic settings where class distinction is prevalent and discriminatory.

The film opens with a rhetorical music score questioning everyday circumstances of the "aggrieved" members of the society represented by the "osu" caste system rhythmically in the Igbo vernacular, summarised by some underlying key words therein like "onyebuchi - "who is god to another person?" and onyemaechi - "who knows tomorrow?" thereby betraying the ideological framework of the encoders as critical of today's Christian living. Like a preachy storyline it is, the film reflects on the circumstances of a girl named Onyebuchi (Comfort Bruno) who is ostracised alongside her family members by being branded "outcasts" in contradistinction to the free-born citizens of the society.

The initial sequence of this movie showcases a successful tilting of camera angles from a wide angle perspective to close up shots detailing an off-horizontal view of a living room belonging to a traditional ruler (Zack Orji) who is engaged on arguments with his wife and daughter. As they discuss village rituals and legislations on the issue of the caste system in their traditional society, one is led to consider their multifarious views as significantly indicative of possible varied opinions on the subject matter. While the king, apparently a modern day, educated Christian believes that the caste 
system is awful and devilish in nature and should be abrogated, his wife, the queen thinks otherwise by arguing that the tradition of their ancestors must not be allowed to be relegated. Thus, throughout the screen time of this storyline suspense is built on attempts at resolving the horrific tension shrouding a culture tinted with Christian values and some ugly traditional practices.

Adaeze (Chinwe Egwuagu) who is the king's only daughter returns from overseas studies and founds a nongovernmental Organization (NGO) to salvage the plights of those ostracised by their community, Umunwanne, especially those belonging to the caste system. She is led by friends to explore and discover the agonies of these people by learning of the story of Onyebuchi who is repeatedly being raped by Uzodimma, the freeborn son of one of the "chiefs" of the king's cabinet called ichie Obidi. Here, Adaeze (Princess) invests all the powers of her strength to fight with her father, the king, to abolish the caste system and restore the dignity of the ostracised members of the society.

The concept of "ichie" is translated "chief" in English language and is used to address elders as those who have distinguished themselves as the custodians of village customs and traditions. As a member of this group that is constantly invited to the king's palace to adjudicate cases in the land, ichie Obidi presents himself as one of those not in favour of abolishing the osu caste system since he believes it is contrary to the dictates of the ancestors and the wishes of their gods. But while he is defending the misconstrued tradition tenaciously, his son Uzodimma is caught betraying everything he opts for secretively by constantly sneaking in to the family of one of the so called "outcasts" and sleeping forcefully with one of their daughters which results into pregnancy. 
Generally, this is traditionally abominable which has the potency of converting the status of ichie Obidi's son from a freeborn citizen to an "osu" but is not pursued here based on the selective discriminatory adjudications of the members of the "ichie" group of Umunwanne.

What this film succeeds in doing is primarily to recast the discriminations of the society against a certain class of indigenes. Again, it problematises the paradox of hypocrisy among Christians who more or less find it difficult to reconcile Christian values with some aspects of African traditional religion (ATR). In the scene that Adaeze reports Uzodimma's case to the king's cabinet, one discovers a momentary division among the chiefs who argue for and against the osu caste system. Especially for ichie Obidi and his group, all about the rape of Onyebuchi should not be discussed in the king's cabinet because she is a slave and inferior to every "free born" of the land like his son, Uzodimma. For him, all members of the osu caste system are not qualified to stand in judgment since they have no rights of their own. What this scene buttresses therefore is the fact that some class of people in the society of Nigeria are undergoing pains due to some cultural discrimination that calls for total overhaul.

It is the overhaul of the discriminatory system that Adaeze attempts to carry out in the film. Even though her mother and some members of the king's cabinet like ichie Obidi are against her, she fights to achieve her aim by plunging headlong into the case involving Onyebuchi and bringing in the police to arrest and imprison him. But like every hypocritical Christian that could abandon his or her case half way in an unfaithful manner she problematises uncommitted Christian living by not "walking her talk." This is depicted when the 
Prince, Ikem, the twin brother of Adaeze returns from the United States of America and falls in love with Onyebuchi to the extent of planning to marry her for good and Adaeze stands vehemently against it even though she had earlier volunteered to give Onyebuchi a better life.

The premise of Adaeze's failure is in the words she uses in admonishing his sibling not to marry Onyebuchi which are cast in discriminatory parlance, thus: "you cannot marry Onyebuchi, Ikem. She is an outcast; you are to be the next king of this village." In other words, despite her struggles to liberate this class of people from discriminatory derogations, she is still of the view that her family is higher in rank and status than the others hence showcasing double standards of judgements. Even when Onyebuchi begs her in tears for forgiveness and understanding, the Princess could not hearken to her voice but throws her out back to the society that had earlier rejected her. This is where lkem moralises the society on personal empowerment and self reliance by speaking to all and Onyebuchi on the significance of Onyebuchi's name as meaning "no one is your God" against all kinds of dependency syndrome, even from his sister.

The measure of pretence and hypocrisy in this film interrogates Christian charity in contextual difficulties which Archbishop Obinna of the Archdiocese of Owerri in Imo State of Nigeria preaches in his special appearance in the film especially in the interview scenes where he speaks to Adaeze and audiences on the way forward in ameliorating the suffering condition of the victims of the osu caste system in the wider society. Like a man of God he is, he calls for a stop against the discriminations that this class of people undergo and challenges the society to have an understanding for the group. This call is substantiated by critically considering the 
sorrows of Onyebuchi who cried throughout the screen time of the movie. In other words, she, not only as a victim of constant sexual harassment but also as one raped by her culture represents the agonies and woes of so many people constantly ridiculed and condemned by their society presently. Thus, the questions at stake in the film are those of the identity and freedom of the ostracised victims of the osu caste system and the possible response of the church at their plights which the next reading situates in the challenges of a Pastor in some unexpected circumstances of life.

\section{Faith and Trials in Act of Faith (2008): Exploring Gospel Values in Personal Context}

Besides the issue of enjoying freedom and peace of mind as Christians are called to is the task of handling earthly challenges with equanimity when they come. This is the storyline of Act of faith, dramatized to moralise family values in the face of earthly upheavals. Directed by Ikenna Aniekwe and produced by Charles Offor, this eighty minutes Nollywood movie, starring artistes like Mike Ezuruonye, Mercy Johnson, Patience Ozokwor, Ify Afuba, Ifeanyi Azodo amongst others helps showcase religious art constructions as ideologically harped on the notion of an absolute being that is good to all and immanent in human affairs. Starting with an establishing shot of Pastor Uche (Mercy Johnson) preaching to a woman faced with marital problems in her office, the movie evokes the problem-solving technique of pastoral communication as a yardstick of its contextual theology. Even though logically framed from the viewpoint of Pentecostal religious theology where prayers are said in utter frenzy by lifting up the Holy bible and expecting God to work mechanically like a machine switched on with a master key, this film explores not only faith challenges in Christian living 
but also negotiates family values in everyday living circumstances.

Lucidly flavoured with biblical quotations to drive arguments along religious sentiments, the film uses Pastor Uche and her husband, Lesley, (Mike Ezuruonye) whose mother (Patience Ozokwor) prefers to call Chidebelu to depict the apparent crisis that young Christian couples face when there are cases of seeming barrenness in their marriage coupled with the everyday worries of the nuclear family pushed often by most mothers-in-law. Here, Lesley's mother does not only disturb her son and wife to bring forth some grandchildren for her honour but also makes serious effort to destroy their marriage when she discovers that things are not going her way.

The storyline is built on suspense grafted on faith and trials in Christian living. The couple have just finished conducting a few days' fasting and praying session to overturn their challenges. Particularly in the scene that betrays their worries, they are seen kneeling very close to themselves and holding each other's hands in prayer on top of their marital bed as they quaked in frenzy with multiple words in petition for a child of their own. It is immediately after this night prayer that Lesley tells the wife that he feels healed of his dysfunctional ailment and goes on to sleep with her in joy like husband and wife unknown to him that danger is lurking nearby. Thus, like every engaging storyline that has to be challenged with the disruption of a normal setting by a villain, their security agent (Boniface) comes to the door calling and reporting of an apparent case of fire outbreak in the compound which not only happens to be a lie but is also a serious scheme to let in a gang of armed robbers to the couple's bedroom that eventually steals and rapes Pastor Uche. 
Even though the encoders of Act of Faith used only a few people in the cast, the storyline is well dramatised that no dull moment is noticed in-between scenes. The intriguing movie suspense is heightened soon after the rape when Pastor Uche becomes mentally challenged due to the trauma of it and had to be taken to a psychiatric hospital. With the help of a counselling therapy, she is systematically stabilized and returns home only to be disturbed further by her mother-in-law clamouring still for grandchildren. Thus, among the many challenges of Pastor Uche in this film are not only those of childlessness and rape but also that of great misunderstanding with her mother-in-law who worried her and Lesley to death because of their apparent infertility problem. At some stage Lesley drives out of his house in annoyance because of his mother and returns home drunk to the chagrin of his wife who asks and admonishes him, thus: "your soul was troubled Lesley and you went to drink? What did that solve? .... Lesley, we are helpless but God will give us help from the Sanctuary and support from Zion....I am grieving Lesley. I feel pain in my heart..."

Even though the situation is unbearable for this couple, faith in God alone is cast as Pastor Uche's only anchor. The bible is like a tool she applies to assuage her worries. For example by quoting and reading aloud I Cor 9: 10 she tells her husband to be patient with the Lord and not lose hope on him who alone can change their situation for the better. The suspense of this movie therefore could be said to hang on the action of God who is expected to intervene in their case. Thus, like every good storyline that climaxes in a resolution, viewers are gradually led to understudy the faith commitments of Pastor Uche to God and her reactions to earthly problems from the beginning to the end as she undergoes her crucibles. 
Generally speaking, the whole issue of Pastor Uche's sufferings in this film in spite of her innocence is the context and site of contextual theology in praxis since it presents her as weak and horribly bruised by circumstances beyond her control even though she is a pastor with strong faith in God. Especially when she becomes emotionally traumatized by the ugly thought of being raped by an unknown armed robber which leads to pregnancy; it behoves imagination to wonder why she has to endure such pains for the nine months of her pregnancy at the silence of a God whom she faithfully serves and even be thrown out of her marital home by the husband she loves who accused her of carrying a potential "bastard" for fear of begetting a thief in his family in the future.

Pastor Uche's sorrows in this film evoke worries in a kind of crisis ridden situation like that of Job and every other suffering soul which ought to necessarily be salvaged by proper contextual theology. Her lamentation alone betrays the state of her pains as can be decoded from the scene where being thrown out of her marital home by her husband, she cries to her mother and audiences in lamentation, thus: "it is not fun for me mama. I feel so much pain deep in my heart. I swallow my saliva. I feel so much agony. I dream horror. I wake up feeling gloomy everyday on earth. I eat my tears mama. I eat these tears because I see nothing but pity. I see the shadow of myself begging God to help me and vindicate me mama."

The final closure of the film resolves the Pastor's problems however pointing to the faithfulness of God who heals and stands by those who seek refuge in him especially in the scene where she is delivered of a child that has a birth mark on his body indicating that after all he is Lesley's since only his family lineage are characteristically identified by such special birth marks. Thus, this is where a twist is presented in 
the movie where Lesley turns round to beg for forgiveness in order to take mother and child home. Like Onyebuchi, Act of Faith interrogates Christian living in today's circumstantial contexts where humanity is insensitive to the humiliating plights of most ridiculed members of the society which is the same case propagated by Cry Freedom where a whole race is made to suffer indignities for so long in the hands of a few leaders charged with leading them to freedom.

\section{Cry Freedom (1987) and the Agony of a Tribe}

The film Cry Freedom directed by Richard Attenborough is highly representational of the ideological prejudices that beclouded the ruling political party of the apartheid days of South Africa and revolves around the true life story of Steve Biko (Denzel Washington) and his friend Donald Woods (Kevin Kline). The establishing shot begins majestically with a faint black screen that awakens the anxiety of the viewer in suspense of wonder. Developing gradually like the dawning of a new day, the screen begins to usher in the harsh sound of some rolling credits hitting the screen surface like electric cracks to unfold the ugly reality of the crisis of South African apartheid history. This completely can be read as a sign of a dangerous omen but subsequently gets thwarted by the normalcy that returns to the screen soon afterwards where a man appears to be doing his early morning shaving and looking out through the window which is used by camera lens to direct viewers to the sensibility of the outdoor crisis in the neighbourhood of some black people of South Africa. Here, the ruling Afrikaans government has sent out troupes to dismantle the black people's quarters for which Steve Biko, their leader is enraged and considers it as capable of instigating racial hatred among his people. 
The charismatic nature of Steve and his power of eloquence makes him charming enough among his people but at the same time presents him as a public enemy of the ruling Afrikaans that has to die for others to move on. Like the battle of races fought by freedom fighters like Mahatma Gandhi and Martin Luther King Junior, Steve Biko stands out to argue against the circumstantial marginalisation of his people and brings his friend, Woods as well as the movie's active audiences to his reasons for disagreeing with the apartheid system of government in the then South Africa. For instance in the scene where he takes Woods round the black people's Community Centre, he is heard to say "we cut your lawns, cook your food, and clean your rubbish..." betraying by this his opposition to the "status quo" of binary opposition that characterise apartheid laws and policies while pointing to the discriminations of the White ruling politicians against the Black race.

The reality of fear and insecurity among people of the Black race is what heightens the suspense of Cry Freedom but at the same time appears to be contrasted with the wide angle shots of Woods and other white people's families enjoying sheltered abodes in harmony. Here the swimming pools in the courtyards of the ruling Afrikaans where their children play around with toys and balloons while the children of the Black race hideaway in fear and anxiety is contrasted. Hence, among the emotionally laden scenes of these binary oppositions cast in flash-backs is that of the nature of the torture of apartheid in relation to even school children. Thus, from a very wide angle shot the screen projects the crowd of innocent unarmed school children passionately chanting Zulu songs along the South African main streets in protest against being forced to take their education in the language of the Afrikaans. They are systematically rounded up by the police 
and mercilessly shot with over seven hundred of them killed and four thousand others wounded. Thus, Cry Freedom can classically be read as laden with historical tortures of the black race while calling for justice and fair play in human interactions without prejudice, discrimination or double dealings. In other words, this scene, it must be said while pointing to the courageous spirit of the black children to die for what they believe in at the same time interrogates the brutality of their deaths as unwarranted in a country that is also theirs. Here, the thrust is that the circumstances of the Black South Africans provided contexts for pastoral theology at a time that could have been used to address their problem as Jesus would but was not done. The film, Romero signals what necessarily ought to have been the response of the Church in the apartheid situation of South Africans by dovetailing the outspokenness of Archbishop Oscar Romero of El Salvador against the injustice of the ruling communist government of his home country, El Salvador at a point in time that popularised "Liberation theology" even though it eventually led to his assassination same way as Jesus died for the masses. The point here is that like a man of God or of the Church he was, he brought succour to the suffering masses of his time by counselling them and speaking out for them in their contextual situations by identifying with their cause of fighting corruption, marginalisation and injustices to bring about healing, consolation and harmonious co-existence for all.

These typical responses that bring about succour and relief as seen in the helping hands offered to the suffering members of the society by most people in the movies analysed is where movies as works of arts help individuals to learn to live morally and socially. In the words of Malone, it is where they serve humanity as "alternative pulpits" and "moral 
compasses" that "direct us to ways of salvation" (2005: 12). They do this by following a ladder of three pillars which is hereby rehearsed to signal the powerful strength of movie art efacts as screen parables in affirming behavioural patterns, challenging cultural attitudes and interrogating conventional worldviews.

\section{Responding to People's Search for Values through Screen Parables: The Case of Movies \\ I) Constructing a Metaphor of Inclusivity}

Movies penetrate the life of individuals to make them "audiences" by constructing engaging storylines around their circumstances. This is the case of inclusivity and proximity. By this approach, the problem of the suffering members of the society in their own contexts are framed metaphorically with integrating symbols that they can identify with. In other words, these films address their needs by reconstructing their identity and experiences logically from insider's perspective in order to effectively address their challenges.

\section{2) Demystifying the "Status Quo" through Social Paradoxes}

This demystification agenda in films is achieved by challenging conventional hegemonic worldviews and interrogating existing social structures by means of subverting storylines which present wisdom as screen parables capable of turning things around didactically. For instance, the paradox in the story of the Good Samaritan changes the "status quo" of thinking about pagans as bad people and the religious people as being "holy". Movies do this by exploring all avenues of creative thinking in order to challenge audiences to a 
new knowledge economy which is in opposition to the everyday thinking pattern of the society. Thus, in the first film analysed, questions are raised over why Onyebuchi as an outcast is forbidden from mixing up with other free citizens of her village while a free son of a traditional lawmaker sneaks in to sleep with her and not incurring the wrath of the gods or that of their leaders. It is here that suspense is often heightened in movies by attempting to problematise the "status quo" of everyday hegemonic worldviews.

\section{3) Resolving Tension through Christonization Principle}

Every good film (like those analysed here) forecloses with a resolution after heightening its suspense in order to hold audiences spell bound. To argue that it resolves through the Christonization principle is to indicate its religious tendency as in being able to see things from the viewpoint of Christ. In other words, it attains its anticlimax point by yielding to messages of gospel values which can be from a human angle perspective like when social evils are overcome in the life of individuals and communities by the help of some "saving forces" or in religious perspective like when God is made to triumph over some excruciating problems of life as happened in Act of Faith or that of receiving a socio-economic redemption like when a helping hand is extended to others to soothe their pains and give them hope for the future.

\section{Conclusion}

Originally this work began by looking at theology from its various angles and triangulating it with the contextual screen parables of African popular films which focus on people's 
everydayness to construct paradoxic storylines. By textualising some select filmography from African cinema, inferences and allusions were made to signal how screen parables emerge from some kind of incarnational and inculturational principles in films with some integrating symbols that help address human experiences practically than theoretically and by so doing interrogate conventional worldviews to bring about new realities imbued with gospel values.

As semiotic ingredients of cultural industry for negotiating paradigms of harmonious existence in the world, especially in Africa and in the global South, the select films for this study were explored as screen parables to review Christian lifestyles, personality characterization and present day communalistic cultural crisis vis-à-vis classical theologies of the Christian world in their responses to people's everyday living-in conditions which led this paper to call for a return to Jesus' own model of evangelisation that consists in self giving sacrifice for the salvation of others. In general therefore, the logic of filmic parables here were used to interrogate systematic theology in order to underscore practical faith sharing experiences of people from movies that resonate with them and emotionally respond to their cry for help by means of addressing their proximate circumstances, confronting their social condemnations and reverting their subjugations towards emancipation and pastoral healing. Thus, these films, while serving as theological parables in the hands of evangelisers especially in people's crisis ridden situations are considered as one way of speaking to the pains of their consumers which classical theologies of Christian faith must emulate if they are to serve their need for the world, especially in present day circumstances where more 
than ever before, humanity is embracing the audio-visual culture of expressing faith related communications.

\section{Endnotes}

1. Peter Malone originally wrote a book entitled "Can Movies Be a Moral compass" and argued that they actually can be because of the ways they influence and direct human attitudes in existential issues. This is the argument extended here by means of nuanced textual analysis of some select movies and logical rhetoric.

2. See Calvin Poulin S. J. (1989). Salvific Invitation and Loving Response: The Fundamental Christian Dialogue. Manila: Queston City.

3. I conducted this focus - group interview on students of the Centre for the Study of African Communication and Culture and those of Imo State University, Owerri in 2008.

4. Ujamma is a Swahili word that is translated "family" used to underscore the concept of communalism in Africa.

5. The quotation appears in Henry V, Act IV. Scene I.

6. By Third World geopolitical zone one refers to the developing nations of the world still faced with difficult problems of healthcare services, economic poverty and political instability.

7. Liberation theology started in Latin America in the 1950s and 1960s and addressed issues of injustice, marginalisation and corruption from the point of view of active resistance from the grassroots. Among other things it challenged mass poverty of the people in Latin America while calling for a return to the gospel values of Jesus.

8. Igbo land refers to one of the major geopolitical zones in Nigeria. It is situated in the South-Eastern part of Nigeria.

\section{References:}

April Springtime. 1995. "Let me hear it From the Church" in Messenger of Saint Anthony. April Edition p27.

Barber, K. 1997. (ed.). Readings in African Popular Culture. Bloomington and Indianapolis: Indiana University Press.

Barlet, O. 2000. African Cinemas: Decolonizing the Gaze. Translated by Chris Turner. London and New York: Zed books.

Bisong, K. 2000. Effective Preaching. Lagos: Smagh and Co. Nigeria Limited. 
Calvin, P. 1989. Salvific Invitation and Loving Response: The Fundamental Christian Dialogue. Manilla: Loyola School of Theology.

Dipio, D. 2009. "Gender and Religion in Nigerian Popular films" in African Communication Research, Vol.2. Number I. St. Augustine University of Tanzania Pp $62-85$.

Fiorenzia, F. S. 1991. "Systematic Theology: Task and Methods". in Fiorenzia F. And Galvin, J. (eds). Systematic Theology: Roman Catholic Perspectives. Volume I. Minneapolis: Fortress Press. Pp I - 89.

Haynes, J. 2000. (ed). Nigerian Video Films. Athens: Ohio University. Center For International Studies.

Iheanacho, D. 2012. Mbaise: Who We Are As a People. Volume One. Owerri: EduEdy Publications.

Larkin, B. 2007. "Itineraries of Indian Cinema: African Videos, Bollywood and Global Media" in

Inda, J. and Rosaldo, R. (eds) in The Anthropology of Globalization: A Reader. Volume 2. Wiley - Blackwell. Pp 335 $35 \mathrm{I}$.

Leske, A. 1998. "Matthew" in the International Bible Commentary: A Catholic and Ecumenical Commentary for the Twenty First Century. Collegeville, Minnesota: The Liturgical Press. Pp $1253-1330$.

Malone, P. 2005. Can Movies Be A Moral Compass? London: St. Pauls Publishing.

Makumba, M. 2006. Natural Theology with African Annotations. Nairobi: Paulines Publications Africa. 
Messaris, P. 1994. Visual Literacy: Image, Mind and Reality. San Francisco and Oxford: West view Press.

Nolan, A. 2006. Jesus Today: A Spirituality of Radical Freedom. Mumbai: St. Pauls.

Ofoegbu, J. 1998. Spirituality of Blessed Cyprain Michael Iwene Tansi: An Afronoid Encounter with Christ. New York: New Africa Publishers.

Onwubiko, O. 1992. Theory and Practice of Inculturation: An African Perspective. Enugu: Snaap Press Limited.

Onwubiko, O. 1993. Facing the Osu Issue in the African Synod: A Personal Response. Enugu: Snaap Press Limited.

Onwubiko. O. 1999. The Church as the Family of God - Ujamaa in the Light of Ecclesia in Africa. Enugu: Falludu Publishing Company.

Plude, F. 20II. "Moving Forward Communication Theology" in Media Development Journal. Vol. LVIII. Pp 9 - I3.

Pontifical Council for Culture. 1999. Towards a Pastoral Approach to Culture. Nairobi: Paulines Publications Africa.

White, R. 1998. "Communication Planning for Church Renewal" in Sunderaj, V. (ed.). Pastoral Planning for Social Communication. Montreal: Paulines. Pp $17-40$.

White, R. 2003. "Theologizing to Communicate God's Love" in Joseph Palakeel (ed). Towards A Communication Theology. Bangalore, India: Asian Trading Corporation. 


\section{Filmography}

Onyebuchim (2010) Directed by Ikechukwu Onyeka, Nollywood, Nigeria

Act of Faith (2008) Directed by Ikenna Aniekwe, Nollywood, Nigeria

Cry Freedom (1987) Directed by Richard Attenborough, United Kingdom

Slum Dog Millionaire (2008) Directed by Danny Boyle and Loveleen Tandan, United Kingdom.

Romero (1989) Directed by John Duigan, Hollywood, United States of America. 